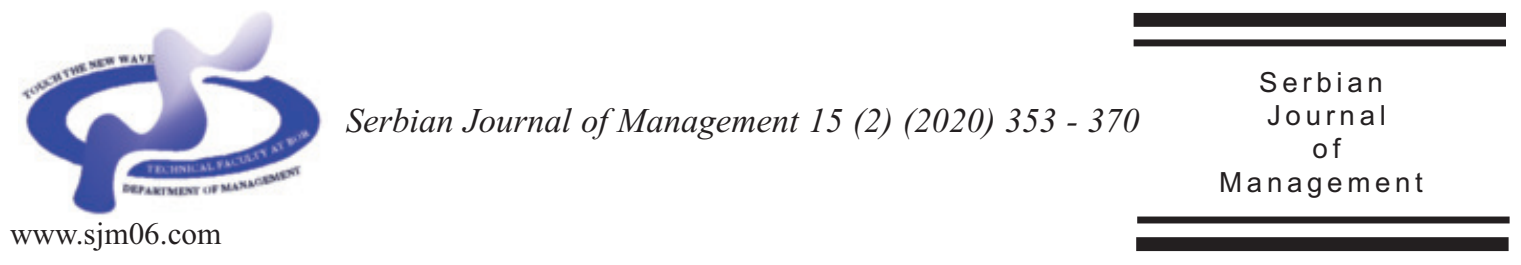

\title{
STRATEGIC HUMAN RESOURCE DEVELOPMENT - A MANOEUVRE FOR FUTURE COMPETENCIES
}

\author{
Hima Parameswaran* \\ Department of Business Administration, \\ Emirates College for Management and Information Technology, \\ Al Nahda - 2, Dubai, United Arab Emirates
}

(Received 03 July 2019; accepted 18 March 2020)

\begin{abstract}
The changing role and function of Human Resource Development professionals due to social, economic, political and technological alterations lead the way for strategic HRD practices in organizations. In this current world of industrialization, this term relates to the achievement of competitive benefits by aligning organizational goals and priorities with structured and futureoriented activities. A study on strategic HRD lends a hand to eliminate the hitches of an organization by rational planning and people development with a focus on predictability and consistency. This research not only enlightens the implication of strategic activities but also it strengthens individual creativity, knowledge management, career planning, and individual competencies amongst employees in industrial sectors. It highlights on the employee perception about these SHRD practices of companies, which is a fundamental factor for the employee contentment, performance, and for the necessity of socio-technical systems. Accordingly, the study is focused at Dubai, U.A.E., in the shape of "Strategic Human Resource Development - A manoeuvre for future competencies" with a sample size of 300 from various companies by quantitative and qualitative analysis. Accordingly, it has been statistically confirmed that four independent variables show a positive relationship with strategic HRD activities. Along with this, it identifies the extent to which the HRD and its related work-life factors are provided by the selected companies. The result of the survey generated a key model and a framework for SHRD by creating a valuable contribution to the organization in facing the future challenges.
\end{abstract}

Key words: individual creativity, knowledge management, career planning, individual competencies, strategic human resource development (SHRD)

\section{INTRODUCTION}

In ensuring organizations with up-to-date management practices in this fast-changing global environment, the responsibility of HRD professionals and senior managers are decisive and demanding (Anderson, 2007). It requires change management and tactical

\footnotetext{
*Corresponding author: himarakesh@gmail.com
}

DOI: $10.5937 /$ sjm15-22393 
methods through deliberate environmental scanning. In this knowledge-based economy, many HRD experts are in dilemma and anxious in relation to the work-life activities in which they are engaged in (McGuire, 2014). In most circumstances the talent force feels uncongenial to discharge their new roles in organizational operational issues. Especially, the rapid growth of information technology, globalization, and industrialization has transformed international business in to a multifaceted structure where every individual must be aware and equipped to meet cross-cultural global players. In light of this, current HRD practices should be responsive to corporate strategy and market trends. Garavan (1991) first defined strategic HRD as 'the strategic management of training, development, and of management/professional education interventions so as to achieve the objectives of the organization while at the same time ensuring the full utilization of the knowledge in details and skills of individual employees.

It is concerned with the management of employee learning for the long-term keeping in mind the explicit corporate and business strategies'. According to Gold et al. (2010) HRD practices itself is strategic and is designed to have a long -term impact. However, they argue that the intent of a strategic approach to HRD is to concern itself with performance at the organizational as opposed to the individual level long-term impact from HRD interventions. Literature provides wide varieties of SHRD measures in organizations depends on its economy, market, social, political and cultural environment (Harrison, 2002; Grieves, 2003; Friedman, 2006; Ulrich, 2007; Mello, 2015; Anderson, 2018). Strategic management process identifies and executes the organization's strategic plan which elucidates company's plan and it specifies how internal strengths and weaknesses match with external opportunities and threats in order to maintain a competitive advantage. Basic steps in this process are translating the mission into strategic goals, formulating strategies to achieve the strategic goals, implementing strategies, and evaluating performance. At this point, the study utilizes the implication of latent constructs namely; creativity, knowledge management, career planning, competencies as SHRD plans in selected industrial sectors.

Creative ideas keep organizations to adjust to the changing market-demand (Shalley et al., 2004), significantly add to levels of innovation, effectiveness and productivity in organizations (Amabile \& Conti, 1999; Nonaka, 1991) and this in turn helps to sustain the growth and could deliver products/services with respect to customer satisfaction (McLean, 2005). Moreover, innovation and creativity cannot flourish in a stringent work environment. Individuals need autonomy and motivation with adequate knowledge sharing, engagement in experimentation, willingness to accept challenges and to foresee new possibilities (Thite, 2004). Encountered with intricate issues, organizations are realizing that it is requisite to build appropriate strategies to foster knowledge creation and share this power to achieve sustainable competitive advantage. To support this, Conley and Zheng (2009) stress that technology is empowering the creation of online communities of practice and is becoming central to assisting the development of effective relationships amongst employees who are geographically dispersed. In this technological world, organizations view career development and planning as an important aspect of identifying, developing 
and retaining their work-force. In addition to this, Sullivan and Mainiero (2007) argue that individuals themselves are greatly aware about their own career planning to achieve a balance between work and family and need to be proactive in managing their careers and in providing outcomes (Sturges et al., 2005). Thus, providing different opportunities for employee development, otherwise, talent development by environmental scanning, employee branding, self-assessment and objective setting, promotion of HR policies and organizational cultures, current and future planning, and developmental needs enhances individual competencies and brings pathway to a competitive advantage in the marketplace for organizations (Souder, 1983; Gandz, 2006; Lievens, 2007; Kucherov \& Zavyalova, 2012).

Hence, this research examines how individual creativity, career planning, knowledge management, and individual competencies can be recognized and fostered in the workplace through organizational and cultural strategies that encourage individual performance amongst employees. In particular, the model manifested from this study could help in bridging the gap between individual desires and organizational outcome.

\subsection{Background to the study}

Dubai, one of the Emirates in U.A.E, the dream land is always renowned for its own growth in tourism, stable political structure, infrastructure, and with most liberal trade systems that attracts many business people from all over the world which guides Dubai a hub for industrial development with work force from over two hundred nationalities. To add feather on its cap, Dubai has won the bid to host Expo
2020, and surely provide an impetus to its economy and employment. According to the reports by World Bank, U.A.E. improved by ten ranks to become the eleventh position in doing business globally (National Business, 2019). In Gender inequality Index, U.A.E. ranked forty-ninth position globally by UNDP reports (Emirates news agency, 2019). Besides, an annual global report published by the Positive Economy Institute since 2013, it stated that the U.A.E. has been ranked eighth on the Positivity Index of Nations, which measures positive economy indicators in OECD member countries (www.arabianbusiness.com). In this above background, this study has heaps of scope towards the above listed variables in SHRD plans and is applicable and reliable in different sectors in Dubai in order to contribute a person's career exploration, establishment, achievement, and fulfilment.

\section{LITERATURE REVIEW}

A variety of strategic human resource development approaches have been developed over the last 20 years to accentuate the human resource management principles and procedures by which organizations can align themselves to the external environment and improve the competences and competencies of their internal processes. Well-known models of strategic HRD are Garavan's (1991, 2007) 'Characteristics of SHRD,' Ulrich's (1998, 2007) 'A new mandate for human resources,' McCracken and Wallace's (2000a) 'Redefining SHRD characteristics,' Harrison's (2002) 'Six critical SHRD indicators,' and Grieve's (2003) 'strategic HRD characteristics.' The synopsis of all models indicates notions such as; that there 
should be a distinct strategy for HRD plans/policies by employee-centered learning and development in aligned with organizational goals, vision and mission, active involvement and commitment of line managers with HRD professionals for continual organizational transformation, adaptability to corporate and diverse culture by environmental scanning and costeffectiveness evaluation. In a global perspective, the insight to SHRD stands in its political changes, labour-market characteristics, technological changes and cross-cultural differences. In relation to this point, Friedman (2006) singles out ten globalization forces which affect the business operations and delivering products and services in today's economy. He argues those forces such as; creation of economic trading, global connectivity, workflow software, communities, outsourcing, offshoring, supply-chaining, insourcing, informing, and personal digital assistants (PDAs) could make organizations more effective and technologically advanced. In 2009 , he added an eleventh force affecting globalization, namely environmentalism and green movement. Therefore, SHRD topic is a continuous process with alterations in organizational policies for its adaptability.

At the same time, some of the bottlenecks for the implementation of SHRD approaches are the involvement of line managers in relation to their work-related activities (Reilly \& Williams, 2006), lack of resistance to change in work delivery, especially in the case of long established companies (Guire, 2014), deficiency of environmental scanning and organizational development (Tamkin, et al., 2006). There are many literatures that highlights on HRD measures which focusses on organizational structures and systems for the purpose of achieving sustainable advantage by controlling human capital (McLagan, 1989; Watkins \& Marsick, 1997; Slotte et. al., 2004). But this study is unique in such a way that, this concentrates on SHRD by increasing human capabilities, emphasis on knowledge management, impact of career planning and implication of individual competencies for proper environmental scanning and proactive steps in selected organizations.

While considering creativity as a latent variable in SHRD, it is understated in the fields of social and organizational psychology and identified six barriers (Sternberg \& Lubart, 1999). Furthermore, different approaches to understand creativity are cognitive (Gardner, 1993), behavioural (Baer et al., 2003), personality (Barron \& Harrington, 1981) and social (Amabile, 1996; Perry-Smith, 2006). In 1999, Feldman identified a multi- factorial approach to examine the creativity where he mentioned about the dependency between perception (work environment, leader support and intrinsic motivation), perspective (cognitive style, prior experience, and risk-taking disposition) and positionality (social, cultural, historical identity) (Feldman, 1999). The main objective is to examine how various variables in creativity can be accepted and adopted in SHRD to encourage risk-taking amongst employees in selected industries. Hence, the first hypothesis formulated for the study is as follows:

Hypothesis 1: The variable, creativity and in organizations has a significant role in SHRD plans to achieve its goals and objectives.

Brown and Duguid (2001) discuss the 'stickiness' related with knowledge sharing, particularly across organizational 
departments. Various social structures in organizations such as project teams, work groups and strategic communities can act as HRD mechanisms for knowledge sharing through which a trust can be created across different departmental units (Blankenship \& Ruona, 2009). In organizations, knowledge management can be considered in four forms. Successful organizations recognize that organizational rules, norms and routines can be 'embedded' within particular local contexts in the form of tacit knowledge (McGuire, 2014). In 'encultured knowledge', culture of an organization guides employees a frame of mindset, through which they can interpret organizational activity (Schein, 2010). Some knowledge sharing is in the form of 'embodied,' where it is related to problem at hand and is strongly applied in its focus. Otherwise, in 'embraced' case, it would be formal or theoretical knowledge which focuses on universal principles and scientific understanding (Lam, 2000). Undoubtedly, knowledge transfer has an imperative role in organizational innovation (Jovanic et al, 2018). Various studies stressed on the lack of appropriate knowledge sharing and its barriers in organizations as individual, organizational and technological barriers in the form of lack of leadership, inappropriate reward system and unsuitable sharing opportunities (Reige, 2005; Gagne, 2009; Conley \& Zheng, 2009). This argument leads to next hypothesis,

Hypothesis 2: The variable, knowledge management in organizations has a significant role in SHRD plans to achieve its goals and objectives.

According to Chen (1998) three wide areas of career are; career as life process, career as individual agency and career as meaning-making. However, modern career concepts are in different angles such as; as boundaryless career (Sommerlund \& Boutaiba, 2007), protean career (Manikoth \& Cseh, 2011), authentic career (Craddock, 2004), kaleidoscopic career (Cabrera, 2009) and portfolio career (Platman, 2003) which insights into the notion that career is not the only obligation of organizations but interest, effort, contribution from the employees' part as well. Based on these above factors, the third hypothesis is as follows;

Hypothesis 3: The variable, career planning in organizations has a significant role in SHRD plans to achieve its goals and objectives.

Garavan et al, 2012 mentioned that employee competencies can be achieved through formal programmes, relationship based and job-based developmental experiences, and both informal and formal developmental activities. Literature identifies that there is much discussion has taken place on the distinction between competences and competencies (Post, 1997; Hafeez \& Essmail, 2007). Mapping employee skills, knowledge, and experience to achieve organization's goals by various strategic activities can increase the competitiveness of the organization. This fact urges to formulate the fourth hypothesis for the study,

Hypothesis 4: The variable, individual competencies in organizations has a significant role in SHRD plans to achieve its goals and objectives.

Hence, all the above factors can be reflected in SHRD process in any organization to achieve an economical advantage in the market-place.

Demographic factors play a pivotal role in 
employee performance and leads to enhance employee productivity and organizational output. For this, creating a culture that manages demographic factors is inevitable (Fernandez, 1991; Hayles \& Mendez, 1997; Auden, 2009; Anderson, 2007). In the light of these evidences, the other objective is to inspect the variation of employees' outlook on the above mentioned latent variables with respect to the demographic factors. Therefore, the influence of demographic factors on each latent variable has measured by following hypothesis.

Firstly, the framed hypotheses for Gender are as follows:

$H_{1 a}$ : The mean score of individual creativity is same for both males and females;

$H_{1 b}$ : The mean score of knowledge management is same for both males and females;

$H_{1 c}$ : The mean score of career planning is same for both males and females;

$H_{1 d}$ : The mean score of individual competency is same for both males and females;

Likewise, for 'Age' the crafted hypotheses are:

$H_{2 a}$ : The mean score of individual creativity is same for all age groups;

$\mathrm{H}_{2 b}$ : The mean score of knowledge management is same for all age groups;

$\mathrm{H}_{2 c}$ : The mean score of career planning is same for all age groups;

$H_{2 d}$ : The mean score of individual competency is same for all age groups;

Similarly, for 'Qualification', the framed hypotheses are:

$H_{3 a}$ : The mean score of individual creativity is same for various qualifications;
$H_{3 b}$ : The mean score of knowledge management is same for various qualifications;

$H_{3 c}$ : The mean score of career planning is same for various qualifications;

$H_{3 d}$ : The mean score of individual competency is same for various qualifications;

For the factor, 'Experience', following are the hypotheses to be tested are:

$H_{4 a}$ : The mean score of individual creativity is same for various experiences

$H_{4 b}$ : The mean score of knowledge management is same for various experiences;

$H_{4 c}$ : The mean score of career planning is same for various experiences;

$H_{4 d}$ : The mean score of individual competency is same for various experiences;

Thus the study combines the above theoretical aspects with identified factors and its relationship with various industrial sectors' work settings.

\section{METHODOLOGY}

The study utilizes adequate theoretical aspects to comprehend the meaning of SHRD for the effectiveness of human resources along with piloted interaction, interviews and a survey aided to realize the deep-rooted insights of employees on their strategic human resource plans in achieving goals.

The pilot study helped to construct a selfstructured, open-ended questionnaire with five-point Likert scale ranging from 'Very good' to 'Very bad' with 30 indicators. It consists of demographic factors in the beginning section, followed by independent variables namely; individual creativity, 
knowledge management, career planning, have mentioned in Table 1.1. and individual competencies towards SHRD. The universe consists of 300 respondents An outline of the questionnaire with from various industrial sectors located in dependent variable and independent Dubai. The method contains both variables and its related measures is quantitative (survey) and qualitative represented in the below table as Table 1. (interview) forms of inquiry. Stratified Also, related factors for four latent variables proportional sampling was used in collecting

Table 1. Variables and Measures

\begin{tabular}{|c|c|c|c|}
\hline SI \# & Variables & Measures & Number of factors \\
\hline \multirow{4}{*}{ Section I } & Demographic factors & Gender & - \\
\hline & & Age & - \\
\hline & & Qualification & - \\
\hline & & Work experience & - \\
\hline \multirow[t]{5}{*}{ Section II } & Independent variables & Individual creativity & 9 \\
\hline & & Knowledge management & 9 \\
\hline & & Career planning & 9 \\
\hline & & Individual competencies & 6 \\
\hline & Dependent variable & SHRD & 30 \\
\hline
\end{tabular}

Source: Literature review and pilot study

\section{Table 1.1. Measures for latent variables}

\begin{tabular}{|c|c|}
\hline Latent variables & Related measures \\
\hline Creativity & $\begin{array}{l}\text { Do you feel a strong urge for expression and wish to develop new products and designs? } \\
\text { Are you an introvert/extrovert or mix of both? } \\
\text { How about your listening skills, observation and abstract thinking skills? } \\
\text { How about your interests, is it in a wide range? } \\
\text { How extend you feel that you are highly focused and committed to your creative endeavors? } \\
\text { How do you feel about the intrinsic and extrinsic motivation from your manger? } \\
\text { How much you are valued in your organization? } \\
\text { How much is your willingness to challenges, risks and failure? }\end{array}$ \\
\hline Knowledge management & $\begin{array}{l}\text { How extent the training provided by your organization? } \\
\text { How much you are adaptable to cultural diversity? } \\
\text { How extent you are socialized (informally) with your team? } \\
\text { Are you up-to-date with the latest technology? } \\
\text { How much creative are you in your work-place? } \\
\text { To what extent you are aware about the organizational goals, and mission? } \\
\text { How extent the supportive and shared leadership in your work? } \\
\text { How do you feel in achieving your aims in life? }\end{array}$ \\
\hline Career planning & $\begin{array}{l}\text { Do you feel your job is secure? } \\
\text { Feeling of competent } \\
\text { Ability to balance work and life } \\
\text { Extent career development activities from your work-place } \\
\text { Receives performance feedback from your superior/manger } \\
\text { Provides academic learning assistance programs from your work-place } \\
\text { Provides mentoring opportunities to support growth and self-direction much you are capable } \\
\text { with your emotional and cognitive skills? }\end{array}$ \\
\hline Individual competencies & $\begin{array}{l}\text { How extend do you feel about your personal ability to plan and organize task? } \\
\text { Capability to work efficiently by accepting and learning from the feedback } \\
\text { Ability to cope with adverse conditions and to solve tactically } \\
\text { How extend you feel that you are result-oriented by mutual cooperation, and } \\
\text { communication? } \\
\text { How do you evaluate your performance appraisal from your work-place? } \\
\text { To what extend you and your organization alert to technological and market trends? }\end{array}$ \\
\hline
\end{tabular}

Source: Literature review and pilot study 
the data as the study consists of demographic factors, which helps to recognize the disparity in employees' outlooks on mentioned latent variables. This can be demonstrated as Table 2.

From the Table 2, it shows that the percentage for gender male (54\%) is more than females, $(46 \%)$ with majority were in age group $41-50,(37 \%)$ and a major share were professionals $(65 \%)$ and of experience with $40 \%$ for $16-20$ years. This helps to acquire a wide notion about their approaches on SHRD components as majority of the respondents were professional and experienced.

\section{DATA ANALYSIS}

The questionnaire for the survey was assessed using Cronbach's alpha for its reliability. Analysis part consists of two stages. The first stage involves descriptive statistics of the measurements to estimate the reliability and validity of the measures applied in this study. Initially, an input model was established using AMOS 18 graphics. Subsequently, the study tested the proposed research model by assessing the contributions and significance of the manifest variables path coefficients. SPSS 20.0 was used to analyze the response from the sample. Another measure, Structural Equation Modelling (SEM) provides a confirmatory approach to the analysis of a structural theory bearing on some phenomenon. It conveys two important aspects of the procedures; a. causal process under study which is represented by a series of structural (regression) equations, and b. these structural relationships can be modelled to facilitate a stronger conceptualization of the theory under study. The hypothesized model is statistically tested simultaneously to examine its consistency with the data through goodness of fit measures. This allows the examination of a series of dependence relationships between exogenous (independent) and endogenous (dependent) variables concurrently and it incorporates the strengths of multiple regression analysis, factor analysis, and

Table 2. Demographic Data

\begin{tabular}{|c|c|c|c|c|}
\hline SI \# & Demographic factors & Measures & Frequency & Percentage \\
\hline \multirow{3}{*}{1} & \multirow{3}{*}{ Gender } & Male & 161 & 53.7 \\
\hline & & Female & 139 & 46.3 \\
\hline & & Total & 300 & 100.0 \\
\hline \multirow{4}{*}{2} & \multirow{4}{*}{ Age } & $30-40$ & 99 & 33.0 \\
\hline & & $41-50$ & 110 & 36.7 \\
\hline & & $51-59$ & 91 & 30.3 \\
\hline & & Total & 300 & 100.0 \\
\hline \multirow{4}{*}{3} & \multirow{4}{*}{ Qualification } & Graduate & 38 & 10.3 \\
\hline & & Post-Graduation & 76 & 24.3 \\
\hline & & Professional & 196 & 65.4 \\
\hline & & Total & 300 & 100.0 \\
\hline \multirow{6}{*}{4} & \multirow{6}{*}{ Experience } & 5-10 & 74 & \\
\hline & & $11-15$ & $\begin{array}{l}14 \\
53\end{array}$ & $\begin{array}{l}24.1 \\
17.7\end{array}$ \\
\hline & & $16-20$ & 89 & 39.7 \\
\hline & & $21-25$ & 68 & 24.7 \\
\hline & & $26-30$ & 16 & 5.2 \\
\hline & & Total & $\begin{array}{r}10 \\
300\end{array}$ & 100.0 \\
\hline
\end{tabular}


multivariate ANOVA. This was done using the two-stage analysis in which the measurement model is first estimated and then the measurement model is kept fixed in the next step in which the structural model is estimated. The justification for this approach is that accurate representation of the indicators' reliability is best accomplished in two steps by avoiding interaction of structural and measurement models. According to the usual procedures, the goodness of fit is measured by checking the statistical and substantive validity of estimates, the convergence of the estimation procedure, the empirical identification of the model, the statistical significance of the parameters, and the goodness of fit to the covariance matrix. Also, parametric statistics like one-way ANOVA and Z-test were used for comparison of the factors considered between different levels of the demographic variables. A level of 0.05 was established as a priority for determining significance.

\section{RESULTS AND DISCUSSION}

Following are the various tests and its measures.

Except for career planning, all other constructs in Table 3, have reliability greater than 0.4 , so further analysis have been proceeded with these variables.

\subsection{Confirmatory Factor Analysis}

As a next step, the study analysis the measurement model of factors to test the convergent validity. Accordingly, all the factors in each dependent variable were tested using Confirmatory Factory Analysis and is represented in Table 4.

All the attributes loaded significantly on the latent constructs. The value of the fit indices indicates a reasonable fit of the measurement model with data. Regression coefficients were also established and is illustrated below as Table 5 .

\section{Table 3. Reliability test}

\begin{tabular}{lcc}
\hline Variables & Cronbach's Alpha & Number of Items \\
\hline Individual creativity & 0.477 & 8 \\
Knowledge management & 0.724 & 8 \\
Career planning & 0.186 & 8 \\
Individual competencies & 0.649 & 6 \\
\hline
\end{tabular}

Table 4. Model fit Indices for CFA

\begin{tabular}{llllllllllll}
\hline Variables & $\boldsymbol{\chi} \mathbf{2}$ & $\mathbf{D F}$ & $\mathbf{P}$ & $\begin{array}{l}\text { Normed } \\
\boldsymbol{2}\end{array}$ & GFI & AGFI & NFI & TLI & CFI & RMR & RMSEA \\
\hline Creativity & 14.318 & 13 & .352 & 1.101 & .988 & .968 & .967 & .993 & .997 & .007 & .018 \\
KM & 33.017 & 7 & .000 & 4.717 & .974 & .866 & .975 & .920 & .980 & .013 & .111 \\
& & & & & .980 & .939 & .946 & .929 & .969 & .014 & .061 \\
CP & 25.476 & 12 & .013 & 2.123 & & & & & & & \\
Competencies & 13.648 & 5 & .018 & 2.7130 & .985 & .939 & .973 & .974 & .982 & .012 & .076 \\
& & & & & & & & & & & \\
\hline
\end{tabular}


For creativity, it explains that the regulatory construct $\mathrm{IC} 1(0.2)$, IC6 (0.1) IC7 (0.1), IC8 (-0.05) has no significant influence as it is less than the recommended value of 0.4. On the other hand, for IC2 (0.6), IC3 (0.6), IC4 (0.5), and IC5 (0.6) p value is significant. For knowledge management, except KM3 and KM6, all other constructs have significant influence on knowledge management as the value is greater than the recommended value. For career planning, results showed that except $\mathrm{CP} 4$ and $\mathrm{CP} 6$ all other constructs, values were $<0.4$ and for last variable four constructs have significant values except for ICo1 and ICo2.
This can be diagrammatically exemplified as Figure 1 to Figure 4 for each variable.

The rectangle specifies observed factors and unobserved factors in the form of ovals. The curved double headed arrows imply correlations or co-variances among the unobserved variables. The straight headed arrow denotes the factor loadings of the observed variables. The small circles with arrows pointing from the circles to the observed variables indicate errors/unique factors otherwise known as squared multiple correlation of the standard error. This initial model is refined to reach the final model.

Table 5. Regression Coefficient

\begin{tabular}{|c|c|c|c|c|c|c|c|}
\hline Variables & Constructs & $\begin{array}{c}\text { Regression } \\
\text { Coefficient }\end{array}$ & $\mathbf{t}$ & $\mathbf{P}$ & $\begin{array}{c}\text { Variance } \\
\text { explained (\%) }\end{array}$ & $\begin{array}{l}\text { Composite } \\
\text { reliability }\end{array}$ & AVE (\%) \\
\hline \multirow[t]{8}{*}{ Creativity } & IC1 & 0.273 & 4.827 & $<0.001$ & 7.4 & \multirow{8}{*}{0.70} & \multirow{8}{*}{20.13} \\
\hline & IC2 & 0.651 & 13.391 & $<0.001$ & 42.3 & & \\
\hline & IC3 & 0.600 & 11.945 & $<0.001$ & 36 & & \\
\hline & IC4 & 0.504 & 9.559 & $<0.001$ & 25.4 & & \\
\hline & IC5 & 0.680 & 14.289 & $<0.001$ & 46.3 & & \\
\hline & IC6 & 0.180 & 3.136 & 0.002 & 3.2 & & \\
\hline & IC7 & 0.009 & 0.155 & 0.877 & 0 & & \\
\hline & IC8 & -0.064 & -1.104 & 0.27 & 0.4 & & \\
\hline Knowledge & KM1 & 0.889 & 24.422 & $<0.001$ & 79 & \multirow{8}{*}{0.56} & \multirow{8}{*}{34.18} \\
\hline \multirow[t]{7}{*}{ Management } & KM2 & 0.422 & 7.757 & $<0.001$ & 17.8 & & \\
\hline & KM3 & 0.371 & 6.714 & $<0.001$ & 13.7 & & \\
\hline & KM4 & -0.112 & -1.938 & 0.054 & 1.3 & & \\
\hline & KM5 & 0.946 & 30.887 & $<0.001$ & 89.4 & & \\
\hline & KM6 & 0.048 & 0.828 & 0.408 & 0.2 & & \\
\hline & KM7 & 0.404 & 7.383 & $<0.001$ & 16.3 & & \\
\hline & KM8 & 0.747 & 16.65 & $<0.001$ & 55.7 & & \\
\hline \multirow{8}{*}{$\begin{array}{l}\text { Career } \\
\text { planning }\end{array}$} & CP1 & 0.742 & 16.457 & $<0.001$ & 55 & \multirow{8}{*}{0.87} & \multirow{8}{*}{17.90} \\
\hline & $\mathrm{CP} 2$ & 0.692 & 14.679 & $<0.001$ & 47.9 & & \\
\hline & $\mathrm{CP} 3$ & 0.252 & 4.438 & $<0.001$ & 6.3 & & \\
\hline & $\mathrm{CP} 4$ & -0.176 & -3.065 & 0.054 & 3.1 & & \\
\hline & CP5 & 0.078 & 1.347 & $<0.001$ & 0.6 & & \\
\hline & CP6 & 0.198 & 3.458 & 0.408 & 3.9 & & \\
\hline & CP7 & -0.420 & -7.715 & $<0.001$ & 17.6 & & \\
\hline & CP8 & 0.296 & 5.259 & $<0.001$ & 8.8 & & \\
\hline \multirow[t]{6}{*}{ Competencies } & & 0.197 & 3.44 & 0.001 & 3.9 & \multirow{6}{*}{0.69} & \multirow{6}{*}{27.60} \\
\hline & ICo1 & 0.176 & 3.065 & 0.002 & 3.1 & & \\
\hline & $\mathrm{ICo} 2$ & 0.771 & 17.626 & $<0.001$ & 59.5 & & \\
\hline & ICo3 & 0.585 & 11.547 & $<0.001$ & 34.2 & & \\
\hline & ICo4 & 0.597 & 11.86 & $<0.001$ & 35.7 & & \\
\hline & $\begin{array}{l}\text { ICo5 } \\
\text { ICo6 }\end{array}$ & 0.540 & 10.412 & $<.001$ & 29.2 & & \\
\hline
\end{tabular}




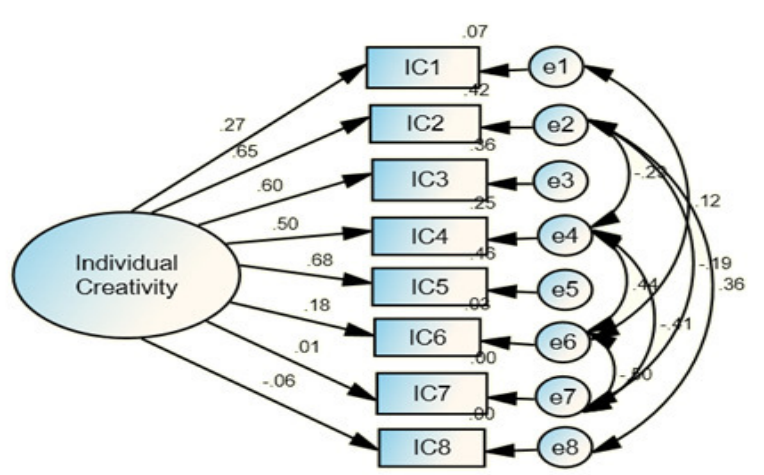

Figure 1. Model for Individual creativity and its related variables

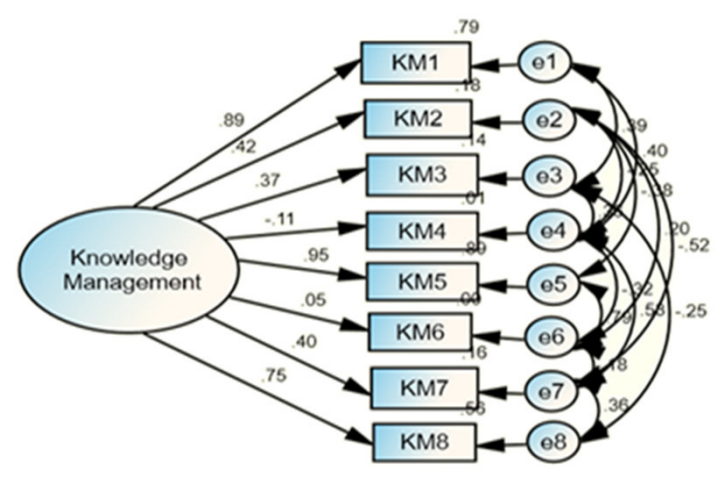

Figure 2. Model for Knowledge Management and related variables

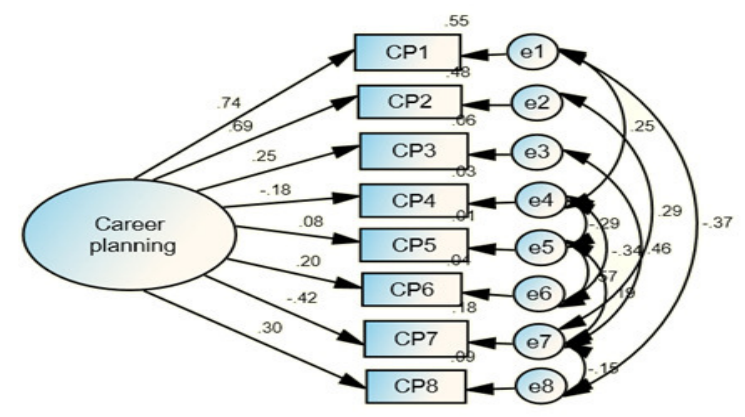

Figure 3. Model for Career planning and its related variables

\subsection{Hypothesis Tests}

The result for hypotheses test is shown as Table 6.

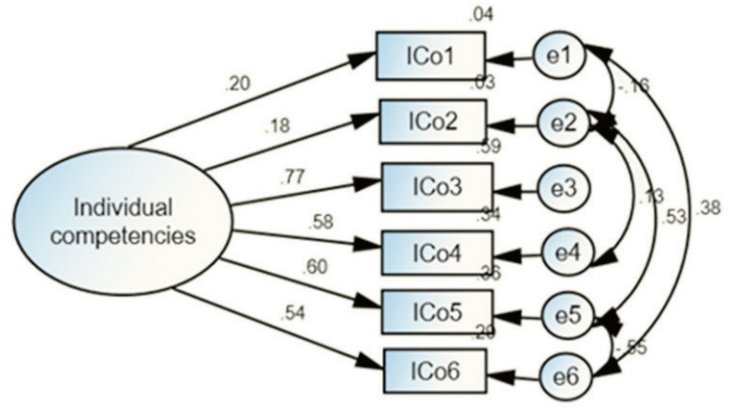

Figure 4. Model for Individual competencies and its related variables

The Table 6 revealed that the regulatory construct, creativity has significant influence on SHRD of the employees as the standardised direct effect of this construct is 0.577, which is more than the recommended value of 0.4 ( $\mathrm{p}$ value is significant). Similarly, for knowledge, it is 1.1 , and for competencies, it is 0.6. But for career, it is 0.2 , which is less than 0.4 and proves that it has no direct significance on SHRD. So, the hypotheses, H1, H2, and $\mathrm{H} 4$ were accepted and $\mathrm{H} 3$ was rejected. Also, this is diagrammatically represented by AMOS 18 graphics to reach the final model as Figure 5.

The Figure 5 clarifies the relationship between each variable towards SHRD. Mapping employee competencies through these above-mentioned variables and determining future challenges can help organizations to achieve the strategic goals and goal-setting procedures.

\subsection{Demographic factors}

Results for Demographic factors for different variables are showed in Table 7.

The result from the Table 7 shows that significant difference exists between males and females for the factors, creativity as the $p$ value is less than 0.05. But, for Knowledge 
Table 6. The regression Coefficients - SHRD

\begin{tabular}{|c|c|c|c|c|c|c|}
\hline Variables & $\begin{array}{l}\text { Regression } \\
\text { Coefficient }\end{array}$ & $\mathbf{t}$ & $\mathbf{P}$ & $\begin{array}{c}\text { Variance } \\
\text { explained (\%) }\end{array}$ & $\begin{array}{l}\text { Composite } \\
\text { reliability }\end{array}$ & AVE (\%) \\
\hline Creativity to SHRD & & 11.339 & $<0.001$ & 33.3 & & \\
\hline Knowledge management to SHRD & & 25.021 & $<0.001$ & 124.5 & & \\
\hline Career planning to SHRD & 1.116 & 3.71 & $<0.001$ & 4.5 & & \\
\hline Competencies to SHRD & $\begin{array}{l}0.212 \\
0.613\end{array}$ & 12.3 & $<0.001$ & 37.6 & 0.74 & 49.98 \\
\hline $\begin{array}{l}\text { IC2 to Creativity } \\
\text { IC } 3 \text { to Creativity } \\
\text { IC } 4 \text { to Creativity } \\
\text { IC5 to Creativity }\end{array}$ & $\begin{array}{l}0.672 \\
0.549 \\
0.534 \\
0.693\end{array}$ & $\begin{array}{l}14.035 \\
10.632 \\
10.267 \\
14.712\end{array}$ & $\begin{array}{l}<0.001 \\
<0.001 \\
<0.001 \\
<0.001\end{array}$ & $\begin{array}{l}45.2 \\
30.1 \\
28.5 \\
48.1\end{array}$ & 0.76 & 37.98 \\
\hline $\begin{array}{l}\text { KM1 to Knowledge management } \\
\text { KM2 to Knowledge management } \\
\text { KM5 to Knowledge management } \\
\text { KM7 to Knowledge management } \\
\text { KM8 to Knowledge management }\end{array}$ & $\begin{array}{c}0.881 \\
0.401 \\
0.943 \\
-0.383 \\
0.775\end{array}$ & $\begin{array}{c}23.786 \\
77.322 \\
30.408 \\
6.955 \\
17.798\end{array}$ & $\begin{array}{l}<0.001 \\
<0.001 \\
<0.001 \\
<0.001 \\
<0.001\end{array}$ & $\begin{array}{c}77.6 \\
16.1 \\
89 \\
14.6 \\
60.1\end{array}$ & 0.60 & 51.48 \\
\hline $\begin{array}{l}\text { CP1 to Career planning } \\
\text { CP2 to Career planning } \\
\text { CP7 to Career planning }\end{array}$ & $\begin{array}{r}0.724 \\
0.694 \\
-0.453\end{array}$ & $\begin{array}{l}15.786 \\
14.746 \\
-8.418\end{array}$ & $\begin{array}{l}<0.001 \\
<0.001 \\
<0.001\end{array}$ & $\begin{array}{l}52.4 \\
48.1 \\
20.5\end{array}$ & 0.95 & 40.33 \\
\hline $\begin{array}{l}\text { ICo3 to individual competencies } \\
\text { ICo } 4 \text { to competencies } \\
\text { ICo5 to competencies } \\
\text { ICo6 to competencies }\end{array}$ & $\begin{array}{l}0.779 \\
0.577 \\
0.638 \\
0.513\end{array}$ & $\begin{array}{c}17.972 \\
11.339 \\
13.008 \\
9.768\end{array}$ & $\begin{array}{l}<0.001 \\
<0.001 \\
<0.001 \\
<0.001\end{array}$ & $\begin{array}{l}60.6 \\
33.3 \\
40.8 \\
26.3\end{array}$ & 0.75 & 40.25 \\
\hline
\end{tabular}

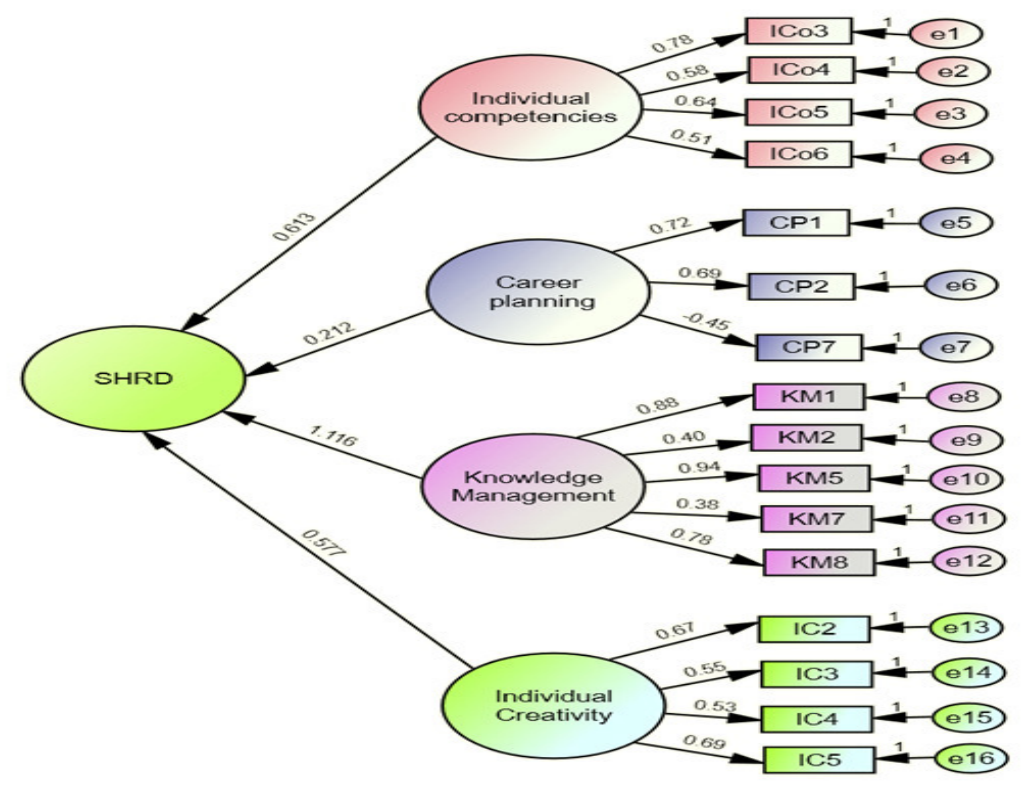

Figure 5. Model for relationship between SHRD and its related variables 
Table 7. Mean, Standard deviation and $z$ value for Gender

\begin{tabular}{llccccc}
\hline Variables & Gender & $\mathbf{N}$ & Mean & $\begin{array}{c}\text { Standard } \\
\text { Deviation }\end{array}$ & $\mathbf{Z}$ & P value \\
\hline Creativity & Male & 168 & 14.96 & 1.49 & 2.420 & 0.016 \\
& Female & 132 & 14.58 & 1.09 & & \\
Knowledge management & Male & 168 & 18.05 & 1.71 & 1.971 & 0.050 \\
& Female & 132 & 17.65 & 1.81 & & \\
Career planning & Male & 168 & 10.70 & 0.81 & 1.593 & 0.112 \\
& Female & 132 & 10.54 & 0.91 & & \multirow{2}{*}{ Competencies } \\
& Male & 168 & 13.45 & 1.19 & -1.690 & 0.092 \\
& Female & 132 & 13.72 & 1.61 & & \\
\hline
\end{tabular}

management, Career planning and Competencies, there is no such significant differences for gender since the $\mathrm{p}$ value is equal to or greater than 0.05 . So, the hypothesis H1a, was rejected and H1b, H1c, H1d were accepted. In the case of Age, it reveals that a statistical value of $p$ is less than 0.05 for the variables Creativity, Knowledge Management and Competencies. It concludes that the mean score for these mentioned variables differs with age groups. Hence, the study rejected the hypotheses $\mathrm{H} 2 \mathrm{a}, \mathrm{H} 2 \mathrm{~b}, \mathrm{H} 2 \mathrm{~d}$, and accept H2c. The result of multiple comparison test indicates that for the variable Creativity, all the age group differs significantly with each other. The results of the ANOVA test for the factors, Qualification and years of Experience reveals that a statistical value of $p$ is less than 0.05 for all the variables considered, which means that the mean scores of all variables differs with qualifications and experiences. Hence, the study rejected the hypothesis H3a to H3d and also, H4a to H4d. Similarly, multiple comparison tests were performed for all other variables to confirm which variable shows difference for qualification and experiences (for age, experience, and qualification tables are not exhibited here).

\section{CONCLUSION}

In this study four variables were investigated towards strategic human resource planning. The above findings are generally more in line and interrelated with the theories of SHRD by Garavan (1991), Ulrich (1998, 2007), McCracken and Wallace (2000a), Harrison (2002), Grieves (2003) that organizations should ensure learning and development activities by knowledge sharing and environmental scanning to know about opportunities and threats. Moreover, the study supports the theories by highlighting the fact that the involvement of line managers with senior managers and good leadership styles in implementing strategic policies.

In the case of variables, firstly, the outcomes strengthen the theoretical aspects on creativity and enlightens new notions. It concludes that all these constructs contribute positively to creativity. This supports the significance of multi-factorial approach (Feldman, 1999) towards creativity in organizations to generate innovative ideas in organizations. It agrees that creativity directly links with risk-taking responsibilities, experiential learning, change environment and constructivist principles by a socially participative atmosphere within the organization. There should be good communication and 
coordination from the top management to line managers in supporting challenging duties, inspiring environment for expressing new ideas and embracing a diverse culture without any racial discrimination. In simple terms, creativity is the combination of cognitive skills, personality, behavioral and social characters (Gardner, 1993; Baer et al., 2003; Barron \& Harrington, 1981; PerrySmith, 2006; Feldman, 1999) as the values for IC1, IC6, IC7, IC 8 are $<4$ (Table 5 and Figure 1).

For knowledge management, these indicators prove that the knowledge about their own organization, its policies/objectives, culture and, working conditions, leadership style, and work-place relationships leads to stability and identity for employees. Naturally, it directs to creative minds in the work place. Employees need up-to-date information on technological changes and clear evidence of organizational goals and mission. In this aspect, four different knowledge concepts namely, embedded (tacit), encultured, embodied and embraced forms are equally important in this selected companies as the values for regression coefficient are $<4$ for KM3, KM4, and KM6 (Table 5 and Figure 2). This proves the priority of knowledge sharing in HRD mechanisms in order to stimulate work-place commitment, relationships, stability and identity to the individuals (McGuire, 2014). So, selected sectors should invest in support to knowledge workers by environmental scanning for its competitiveness and survivability.

Besides, the results clarified that career planning (values for $\mathrm{CP} 1, \mathrm{CP} 2$, and $\mathrm{CP} 7$ is $>4$ in Table 5 and Figure 3 ) is not the only responsibility of a particular organization, but the perception, perspective, and cognitive skills of individuals about their career, in different terms as as boundaryless career (Sommerlund \& Boutaiba, 2007), protean career (Manikoth \& Cseh, 2011), authentic career (Craddock, 2004), kaleidoscopic career (Cabrera, 2009) and portfolio career (Platman, 2003), is crucial in their career growth. In order to achieve their goals in life by retaining their employability, training and development from organizations, learning assistance programs, and adequate mentoring are necessary. Thus, employees can maintain a good work-life balance and perform well in their various roles such as a spouse, a parent, a good citizen to the society and to the entire nation. But, certainly, the study stipulates that some kind of career inventory instruments can be incorporated in sectors for guiding them to select their jobs. Also, career counselling and continuous professional development are imperative to ensure a good fit between individuals' personality and occupational selections and to update knowledge, skills and connect with other learners. Lastly, for individual competencies, extrinsic and intrinsic rewards by a flawless, transparent and accountable process based on their performance are imperative in organizations as it is evident from the values for ICol and ICo2, $<4$ (Table 5 and Figure 4). This maintains the concept that employees need both formal and informal activities in their skill development (Garavan et. al., 2012).

Demographic factors should also be considered in SHRD plans as the result proves the variation in their outlooks towards SHRD practices towards the employee productivity.

Further, this study has lots of scope for future researches as SHRD activities are very complex and dynamic in this turbulent world. In recent times, this notion in organizations is becoming increasingly important as work becomes internationalized 
to a greater degree and needs to place a stronger emphasis on creativity, knowledge management, competencies and, of course, results for career planning explains the need for new strategies. Future study can be concentrated using other work-life variables in other sectors in U.A.E and internationally as well. As a result of current recessionary pressures and job insecurity, there is an increasing attention and prominence on SHRD practices in organizations by employee branding and benchmarking. In order to support employment and economic developments, Dubai government always supports for more events such as World Economic Forum, Global Innovation Summit, Public Policy Forum and World Tolerance Summit every year for exchanging ideas and knowledge globally. Hence, in all aspect this study could shed light on the future policy formulation and implementation procedures in all sectors of employment.

It is equally important to point the limitations for the study. The human feelings and motives are always changing according to their socio-environmental factors and could be subjective during the survey/interaction/interviews. Additionally, it is to be emphasized that the abovementioned variables are not the only tactics in SHRD in an organization, so the employees' priority depends on its strategies, policies, vision and mission.

\section{References}

Amabile, T.M., Conti, R., Coon, H., Lazenby, J. \& Herron, M. (1996). Assessing the Work Environment for Creativity. Academy of Management Journal, 39 (5), 1154-1185.
Amabile, T.M. \& Conti, R. (1999). Changes in the World Environment for Creativity during Downsizing. Academy of Management Journal, 42 (6), 630-640.

Anderson, V. (2007). Desperately Seeking Alignment: Reflections of Senior Line Managers and HRD Executives. Human Resource Development International, 12 (3), 263-277.

Anderson, M. (2007) Diversity Learning, Knowledge Diversity, and Inclusion: Theory and Practice as Exemplified by Corporate Universities. Equal Opportunities International, 26(8) 743-760.

Anderson, E.V.C. (2018). Leading an HR Transformation: A Practical Roadmap for Aligning People Strategies to Business Results (1st Ed.), Society for Human Resource Management, 12(3), 263-277.

Auden, W. (2009). Top Management Team and Firm Performance: Empirical Study Based on Companies Listed Under S. Ohio: LAP Lambert Acad. Publ.

Baer, M., Oldham, G.R. \& Cummings, A. (2003). Rewarding Creativity: When does it Really Matter? The Leadership Quarterly, 14 (4), 569-586.

Barron, F. \& Harrington, D.M. (1981). Creativity, Intelligence and Personality. Annual Review of Psychology, 32, 439-476.

Blankenship, S.S. \& Ruona, W.E.A. (2009). Exploring Knowledge Sharing in Social Structures: Potential Contributions to an Overall Knowledge Management Strategy. Advances in Developing Human Resources, 11(3), 290-306.

Brown, J.S. \& Duguid, P. (2001). Knowledge and Organization: A Socialpractise Perspective. Organization Science, 12 (2), 198-213.

Cabrera, E.F. (2009). Protean Organizations: Reshaping Work and Careers to Retain Female Talent. Career Development International, 14 (2), 186-201. 


\section{СТРАТЕШКИ РАЗВОЈ ЉУДСКИХ РЕСУРСА - МАНЕВАР ЗА БУДУЋЕ КОМПЕТЕНЦИЈЕ}

\section{Hima Parameswaran}

\section{Извод}

Променљива улога и функција стручњака за развој људских ресурса услед социјалних, економских, политичких и технолошких промена доводи до праксе увођења стратешког развоја људских ресурса у организацијама. У данашњем свету индустријализације, овај термин се односи на постизање конкурентских користи усклађивањем организационих циљева и приоритета са структурираним и будућим оријентисаним активностима. Студија о стратешком развоју људских ресурса пружа могућност за уклањање проблема организације рационалним планирањем и развојем људи, са фокусом на предвидљивост и доследност. Ово истраживање не само да расветљава импликације стратешких активности већ и јача индивидуалну креативност, управљање знањем, планирање каријере и индивидуалне компетенције међу запосленима у индустријским секторима. Такође, наглашава перцепцију запослених о примени стратешког развоја људских ресурса у компанији, што је основни фактор за задовољство запослених, учинак и неопходност социо-техничких система. Сходно томе, студија је усредсређена на Дубаи, У.А.Е., у облику „Стратешки развој људских ресурса маневар за будуће компетенције“ где је величина узорка износила 300 испитаниа из различитих компанија укључујући квантитативну и квалитативну анализу. Сходно томе, статистички је потврђено да четири независне променљиве показују позитивну везу са стратешким активностима на пољу људских ресурса. Поред тога, идентификује се у којој мери одабране компаније пружају развој људских ресурса и с њим повезане факторе радног и животног века. Резултати анкете створили су кључни модел и оквир за стратешки развој људских ресурса стварањем драгоценог доприноса организацији у суочавању са будућим изазовима.

Кључне речи: индивидуална креативност, управљање знањем, планирање каријере, индивидуалне компетенције, стратешки развој људских ресурса

Chen, C. (1998). Understanding Career Development: A Convergence of Perspectives. Journal Vocational Education and Training, 50(3), 437-461.

Craddock, M. (2004). The Authentic Career. Following the Path of Self-discovery to Professional Fulfillment. Novato, CA: New World Library.

Conley, C.A. \& Zheng, W. (2009). Factors Critical to Knowledge Management Success. Advances Developing Human Resources, 11 (3), 290-306.
Emirates
News

https://www.wam.ae/en/details/1395302809 096.

Fernandez, J. (1991). Managing a diverse Workforce. New York, US: Lexington Books.

Friedman, T.L. (2006). The World is Flat: The Globalized World in the Twenty-first Century. London, UK: Penguin.

Feldman, D.H. (1999) The Development of Creativity: In R.J. Sternberg (ed), Handbook of Creativity, Cambridge: Cambridge University Press.

Gagne, M. (2009). A Model of 
Knowledge-sharing Motivation. Human Resource Management, 48 (4), 571-589.

Gandz, J. (2006). Talent Development: The Architecture of a Talent Pipeline that Works. Ivey Business Journal Online (January/February), 1-4.

Garavan, T.N. (1991). Strategic Human

Resource Development. Journal of European Industrial Training, 15 (1), 21-34.

Garavan, T.N., Carbery, R. \& Rock, A. (2012). Mapping Talent Development: Definition, Scope and Architecture. European Journal of Training and Development. 36 (1), 144-164.

Garavan, T.N. (2007) A Strategic Perspective on HRD. Advances in Developing Human Resources, 9(1), 11-30.

Gardner, H. (1993). Creating Minds: An Anatomy of Creativity Seen through the Livers of Freud, Einstein, Picasso, Stravinsky, Eliot, Graham and Gandhi. New York, US: Basic Books.

Grieves, J. (2003). Strategic Human Resource Development. London, UK: Sage

Gold, J., Holden, R., Illes, P., Stewart, J. \& Beardwell, J. (2010). Human Resource Development Theory and Practice. Basingstoke: Palgrave Macmillan. Gulf news, March 11, 2019.

Hafeez, K. \& Essmail, E.A. (2007). Evaluating Organization Core Comoetencies and Associated Personal Competencies Using Analytical Hierarchy Process. Management Research News, 30 (8), 530547.

Harrison, R. (2002). Learning and Development. London: CIPD.

Hayles, R., \& Mendez, R.A. (1997). The Diversity Directive. New York, US: McGraw-Hill.

Jovanovic, I., Arsic, M., \& Nikolic, D. (2018). Entrepreneurial Personality Traits and SMEs Profitability in Transition
Economy. Serbian Journal of Management 13 (1) 89-104.

Kucherov, D. \& Zavyalova, E. (2012). HRD Practices and Talent Management in the Companies with the Employer Brand. European Journal of Training and Development, 36 (1), 86-104.

Lievens, F. (2007). Employer Branding in the Belgian Army: The Importance of Instrumental and Symbolic Beliefs for Potential Applicants and Military Employees. Human Resource Management, 46 (1), 51-69.

Lam, A. (2000). Tacit Knowledge, Organizational Learning and Societal Institutions: An Integrated Framework. Organisation Studies, 21 (3). 487-513.

Manikoth, N.N. \& Cseh, M. (2011). Career Behavioiur Patterns of Professional Women: A study of Protean Careers. Paper presented at the 2011 AHRD International Research Conference in the Americas, Schaumberg, Chicago, 23-26 February.

McCracken, M. \& Wallace, M. (2000a). Towards a Redefinition of Strategic HRD. Journal of European Industrial Training, 24 (5), 281-290.

McGuire, D. (2014). Human Resource Development, 2nd edn. London, UK: Sage.

McLagan, P. (1989). Models for HRD Practice. Alexandria, VA: ASTD Press.

McLean, L. (2005). Organizational Culture's Influence on creativity and Innovation: A Review of the Literature and Implications for Human Resource Development. Advances in Developing Human Resources, 7 (2), 226-246.

Mello, A. J., (2015). Strategic Human Resource Management, 4th edn. United States: Cengage.

Nonaka, I. (1991). The Knowledgecreating Company. Harvard Business Review, 69 (6), 96-104. 
Platman, K. (2003). The Self-designed Career in Later Life: A Study of Older Portfolio Workers in the United Kingdom. Ageing and Society, 23 (3), 281-302.

Post, H.A. (1997). Building a Strategy on Competencies. Long Range Planning, 30 (5) 733-740.

Reige, A. (2005). Three-dozen Knowledge Sharing Barriers Managers Must Consider. Journal of Knowledge Management, 9 (3), 18-35.

Reilly, P. \& Williams, T. (2006). Strategic HR: Building the Capability to Deliver. London: Gower.

Schein. E.H. (2010). Organizational Culture and Leadership, 4 th edn. San Francisco. CA: Jossey - Bass.

Shalley, C.E., Zhou, J. \& Oldham, G.R. (2004). The Effects of Personal and Contextual Characteristics on Creativity: Where Should We Go from Here? Journal of Management, 30 (6), 933-958.

Sommerlund, J. \& Boutaiba, S. (2007). Borders of 'The Boundaryless Career'. Journal of Organizational Change Management. 20(4), 525-538.

Souder, W. (1983). Planning a Career Path from Engineering to Management. Engineering Management International, 1 (4), 249-258.

Sternberg, R.J. \& Lubart, T.I. (1999). The Concept of Creativity: Prospects and Paradigms. In R.J. Sternberg (ed), Handbook of Creativity. Cambridge: Cambridge University Press.

Sturges, J., Conway, N., Guest, D. \& Liefooghe, A. (2005). Managing the Career Deal: The Psychological Contract as a Framework for Understanding Career Management, Organizational Commitment and Work Behaviour. Journal of Organizational Behaviour, 26 (7), 821-838.

Sullivan, S.E. \& Mainiero, L.A. (2007).
The Changing Nature of Gender Roles, Alpha/Beta Careers -Bassand Work-Life Issues: Theory-driven Implications for Human Resource Management. Career Development International, 12 (3), 238-263.

Slotte, V., Tynjala, P. \& Hytonen, T., (2004). How do HRD Practitioners Describe Learning at Work? Human Resource Development International, 7(4), 547-544.

Perry-Smith, J.E. (2006). Social Yet Creative: The Role of Social Relationships in Facilitating Individual creativity. Academy of Management Journal, 49 (1), 85-101.

Tamkin, P., Reilly, P. \& Strebler, M. (2006). Change Agenda: The Changing HR Function-The Key Questions. London: CIPD.

Thite, M. (2004). Managing People in the New Economy. Thousand Oaks, CA: Sage.

Ulrich, D. (1998). A New Mandate for Human Resources. Harvard Business Review, 76 (1):124-34.

Ulrich, D. (2007) Dreams: Where Human Resource Development is Headed to Deliver Value. Human Resource Development Quarterly, 18(1), 1-8.

Watkins, K.E. \& Marsick, V. (1994). Sculpting the Learning Organisation: Lessons in the Art and Science of Systemic Change. San Francisco. CA: Jossey-Bass.

\section{Web references}

www.arabianbusiness.com

www.thenational.ae. January 21, 2019. 